\title{
Analysis of Internal Customer Satisfaction Related to The Service of The Medical Record at Muhammadiyah Public Hospital Ponorogo
}

\author{
Etik Mardyantari ${ }^{1}$, Sandu \\ Siyoto $^{2}$, Sentot Imam $^{3}$ \\ ${ }^{1}$ Medical Records and Health \\ Information of High School of \\ Health Sciences Buana \\ Husada Ponorogo, Indonesia \\ ${ }^{2}$ IIK STRADA Indonesia \\ ${ }^{3}$ IIK STRADA Indonesia \\ Email: \\ etikiskandar14@gmail.com
}

Received: March $8^{\text {th }} 2021$

Accepted : April 15 2021

Published : May $20^{\text {th }} 2021$

\begin{abstract}
The medical record department is one of the most important parts in the hospital's effort to provide excellent service to patients. The medical records section is indeed a part that is not directly involved in patient care, but other health workers need a medical record section in order to serve patients. The purpose of this study was to analyze internal customer satisfaction related to the service of the medical records department at Muhammadiyah Hospital Ponorogo. The research design used a descriptive quantitative research design. The sampling technique used was snowball sampling. The results showed that several obstacles were found, namely the speed of providing medical records, the accuracy of providing medical records, the management of KLPCM (Incomplete Filling Of Medical Records) and medical record officers who had medical record competence were still very limited. Improved services provided by the medical record department can increase internal customer satisfaction, and of course will have a direct impact on service to patients. nurses and hospital BPJS healthcare officers.
\end{abstract}

Keywords: Medical records, internal customers, satisfaction \begin{abstract}
International License.
\end{abstract}
This is an open-acces article distributed under the terms of the Creative Commons Attribution-ShareAlike 4.0

\section{INTRODUCTION}

The hospital is one of the public facilities used to organize health efforts and increase the degree of health. In an effort to provide medical services to patients, the hospital involves several units or sections, one of which is part of the medical record. The medical record department at the hospital is one of the parts that plays an important role in the success of services to hospital residents. The medical records section is the spearhead of hospital services, because medical record activities start from the patient registration process to the reporting and presentation of hospital health service process data.

The medical record division as the spearhead and spearhead of health services certainly involves all health workers, such as doctors, nurses, midwives, nutritionists and so on in providing health services. Medical personnel who every day intersect with the medical record department in order to provide services to patients include doctors and nurses as partners in filling, completing and communicating related medical record documents. Meanwhile, other health workers who intersect with the medical record section are BPJS hospital officers in the context of managing BPJS healthcare claims.

The medical records department as a unit that serves health workers in their work, of course, must always provide good quality service and facilities, so that customers feel satisfied regarding the 
service of the medical records department. Menuru Tjiptono (2010) states that quality has a close relationship with customer satisfaction. Quality provides an incentive for consumers to form strong relationships with service provider institutions. Meanwhile, the main problem as a service provider institution is whether the services provided are in accordance with customer / consumer expectations or not. Therefore, the medical record department, as part of the service provider, is required to always maintain customer trust by improving the quality of its services. Establishing relationships and researching them needs to be done so that the services provided are in accordance with expectations, so that by knowing the customer perceptions of the services provided, the medical records department can improve and improve its quality.

The results of a preliminary study conducted at the Muhammadiyah Hospital of Ponorogo, stated that the relationship between the medical records department and doctors / nurses was related to requests for multiple medical records, provision of medical records, design of medical record forms, borrowing and storing medical records and completeness of accreditation. From the relationship between doctors / nurses and the medical record department, there were several problems including $30 \%$ of medical records in October 2019 were incomplete, 42 medical record documents changed format in 2019, medical record missfiles, errors in providing medical records and miscommunication related to methods patient payment. While the relationship between the medical record section and the BPJS healthcare section is related to the completeness of the file as a condition for claiming treatment costs, currently the BPJS healthcare verifier is the hospital itself, resulting in that the medical record files that are included for the claim are not only medical resumes but all evidence of health services provided to patients. The purpose of this study is to analyze internal customer satisfaction related to the service of the medical records department at Muhammadiyah Hospital Ponorogo.

\section{MATERIALS AND METHODS}

This study used a quantitative descriptive research design with a case study approach. The informants in this study were doctors / dentists, nurses and the BPJS healthcare division of the hospital, using techniques Snowball sampling. This research instrument uses a questionnaire to determine the order of the values of the dimensions of internal customer satisfaction which includes reliability, responsiveness, assurance and empathy and uses interview guidelines to analyze internal customer satisfaction with the service of the medical record department. The data collection techniques in this study used questionnaires and in-depth interviews with informants. Data analysis in this study used quantitative-qualitative data analysis in stages, where the researcher would collect quantitative data followed by qualitative data analysis. While the validity of the data in this study used source triangulation. This research has been carried out by reviewing ethics by the Health Research Ethics Commission of IIK Strada Indonesia Kediri number: 1705 / $\mathrm{KEPK} / \mathrm{I} / 2020$.

\section{RESULTS}

\section{GENERAL DESCRIPTION OF INFORMATION}

Research informants / participants are the main component, which must be fulfilled in research. Research informants are components that are the main determinants of the success of a study. The informants in this study were internal customers from the medical records department at the Muhammadiyah Ponorogo General Hospital. Internal customers who became informants in this study were medical and non-medical personnel who worked at Muhammadiyah Hospital Ponorogo. Medical personnel who became informants in this study were doctors and nurses, while non-medical personnel who were informants of this study were part of BPJS healthcare officers at Muhammadiyah Hospital Ponorogo.

The informants in this study who filled out a questionnaire related to the dimensions of internal customer satisfaction consisted of 84 people, consisting of 5 doctors / dentists, 77 nurses and 2 people from the BPJS healthcare hospital. Meanwhile, the informants who conducted in-depth interviews to analyze internal customer satisfaction consisted of 7 people.

\section{QUESTIONNAIRE FILLING RESULTS 4 DIMENSIONS OF INTERNAL CUSTOMER SATISFACTION}

The data generated in filling out this questionnaire is the informant's assessment related to the informants' perceptions and expectations of the services of the medical record department at Muhammadiyah Hospital of Ponorogo. Researchers obtained data from informants by distributing 
assessment questionnaires to informants and the researcher reading out the dimensions of the questions to be assessed. The assessment dimension is divided into 20 questions which are grouped into 4 assessment dimensions, namely the reliability of the officers, the responsiveness of the officers, the assurance and the empathy of the officers.

The informants filled out a questionnaire by providing a value ranging from 1-5 related to their perceptions and expectations on each question on the dimensions of internal customer satisfaction. After all the informants filled out the questionnaire, then the researcher calculated the difference between the expected value and the informant's perception of the service in the medical record department. The results of the calculation are then accumulated / added up to find out the largest order of the 4 dimensions of internal customer satisfaction with medical record services.

The largest order of the sum of the differences in expectations and perceptions of informants towards the service of the medical record department is responsiveness with a value of 353 , reliability with a value of 348, assurance with a value of 93 and empathy with a value of 50 .

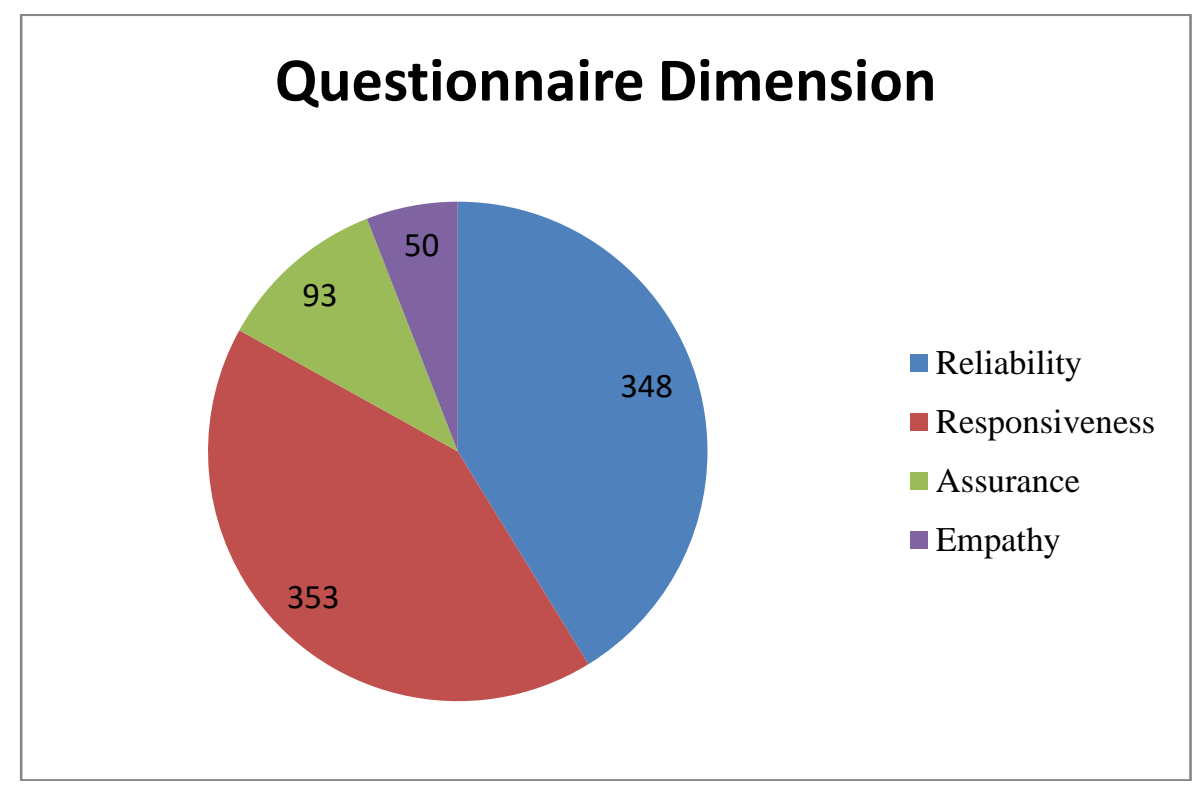

Figure 1. The gap between the expectations value and the perceptions of the informants

\section{RESULTS OF DEEP INTERVIEW GUIDELINES}

The questions from the in-depth interview consisted of several things related to their perceptions and expectations related to the service of the medical records department at Muhammadiyah Hospital of Ponorogo. Following are the results of in-depth interviews with research informants:

1. The importance of the medical record for the hospital

All informants considered that medical records were important, because medical records were the basis for providing services to patients, because in medical records all medical records were written. In addition, medical records also function to record the patient's condition. The informant also said that the medical records section is an important part of the hospital as a support for patient services.

2. The existence of a medical records section

All respondents are aware of the existence of the medical records section at Muhammadiyah Hospital Ponorogo, which is on the 1st floor of the new Muhammadiyah Hospital Ponorogo building, but registration is still divided into two parts of the old building and the new building.

3. Informants' perceptions related to medical record officers

Almost all informants knew the name of the head of medical records at Muhammadiyah Hospital Ponorogo, but related to the number of employees in the medical records department, all informants did not answer certainty the number of employees in the medical records. Regarding the qualifications / competence of employees in the medical records section, the informant said that there was only 1 staff with a Diploma 3 degree of medical record qualification and the others had a high school education or a non-medical record degree.

The informant hopes that in the future there will be additional medical record personnel who have Diploma 3 degree of medical record educational qualifications, or if not for the time being, the existing personnel will be given or include training related to medical records.

4. Communication with medical records 
The informant said that for communication with the medical records department, most of them were related to requests for medical records for patient treatment, BPJS healthcare management, as well as for completing medical record contents.

Informants also provide information, especially for nurses, that not all nurses are able to communicate intensively with the medical records department, this is because based on the accreditation rules, the nurse in charge of the shift has the right to fill and complete the lack of medical record contents. Other communications that the informant has made with the medical records department include meetings, especially during accreditation, routine section head meetings and meetings related to changes or additions to medical record forms.

5. The accuracy of officers in providing medical records

The informant said that the medical record officers in providing the requested medical records had already matched the names of the patients who were going to take medication. But the informant also said that there were some old patient medical records that were not included in the new files, especially this had happened in the ICU and the treatment room. So, this will also hinder the process of treatment / care services to patients, because doctors or nurses sometimes need a patient's history to determine further action / treatment.

6. Responsiveness of providing patient medical records

The results of interviews with informants related to the speed / responsiveness of medical record officers in providing the required medical records were still lacking. This has happened to emergency room patients, ICU and treatment rooms.

The delay in providing medical record files, according to the informant, will greatly hamper service to patients, this will also result in complaints from patients. For example, in the ICU, especially for patients who enter at night (with the excuse that only 1 person is on duty), files are provided in the morning, and even then the ICU officer reminds them repeatedly, even for up to 2 days, new medical records were delivered by officers. This will hinder medical personnel from providing services to patients.

Delays in providing medical records also occurred in the ER. This will result in compalin from patient to staff, because for old patients who enter the emergency room and have to undergo treatment in the treatment room, they have to wait for the medical record to be available first, then the patient and medical record are simultaneously delivered to the treatment room.

7. Incomplete Filling of Medical Records / KLPCM

KLPCM is a medical record file that is incomplete to be filled in by medical personnel after the patient returns and has been returned to the medical records section. According to the informant, the medical record officer was not routine in requesting the completeness of medical records from medical officers. This will result in an accumulation of medical personnel in completing medical records and will interfere with other activities. In addition, the informant also said that the medical record officer in providing information on the parts that needed to be completed was unclear, the medical record officer only wrote down which sheet needed to be completed, without writing down which part of the sheet had to be completed, so that sometimes the medical staff was confused in filling it out. The informant also conveyed that medical record officers did not understand who was obliged to complete the contents of the medical record.

\section{DISCUSSION}

Research with the topic of analyzing internal customer satisfaction related to the service of the medical records department at Muhammadiyah Hospital of Ponorogo involved 84 informants, consisting of doctors, nurses and BPJS hospital employees. The informant filled out a questionnaire read by the researcher by giving the informant's perceptions and expectations value for the services of the medical record department of the Muhammadiyah Hospital of Ponorogo.

The questionnaire contains as many as 20 questions which are grouped into 4 question dimensions, namely reliability, responsiveness, assurance and empathy. Informants provide an assessment of each question dimension both in terms of informant perceptions and informant expectations. After all the questionnaires have been collected, the researcher then calculates the gap between perceptions and expectations, then adds up which gaps are the biggest of the four question dimensions. The largest order of the sum of the differences in expectations and perceptions of informants towards the service of the medical record department is responsiveness with a value of 353 , reliability with a value of 348, assurance with a value of 93 and empathy with a value of 50 .

This means that according to the informant, medical record officers have a good sense of empathy for other officers and are able to maintain what internal customers have consulted with medical records officers. This was reinforced by the results of in-depth interviews by researchers with 
several informants, which stated that medical record officers had good behavior, were polite and respected other officers.

The biggest question dimension is in the question dimension of reliability and responsiveness. Reliability here is a question related to the ability of medical record officers to carry out their work in accordance with their duties and authority as well as the competencies possessed by medical record personnel and communication with other health workers, especially internal customers who are informants in this study (doctors, nurses and BPJS healthcare employees. ). The fundamental thing that is the main point that will be discussed in the dimension of reliability is the ability of medical record officers to carry out their main duties with internal customers. Some internal customers said that the medical record officer in providing patient medical records in accordance with the medical staff's request. However, the problem for medical officers according to informants is that there are several medical records, especially old patients, old medical records are not included. This of course will hinder medical personnel in providing services to patients, because doctors always look at the history of the patient's condition when taking action / treatment. One example of the incident was an old patient who entered the ICU at night whose medical records were not included, so that doctors and nurses had difficulty knowing what drugs had been given to patients, because according to the informants' information there was one drug that was only given once a living well. Another example is in the treatment room, there are old patients who are hospitalized again, and doctors ask for old medical records to find out the history of the patient's condition. but old medical records were not included. This is very ironic because the medical record numbering system at Muhammadiyah Ponorogo Hospital uses a centralized storage and unit system, which means that all medical records of inpatients, roads and emergencies are put together in one folder / folder and stored in one medical record number.

Another problem felt by informants related to the reliability of medical record officers was related to KLPCM (Incompleteness of Filling in Medical Records). The information conveyed by the informants was that medical record officers often deposited incomplete medical records not regularly, there were informants who said that more than once a month they deposited incomplete files. According to the informant, this would interfere with the main work of medical officers in providing services to patients, and on the other hand, medical records must be completed immediately and returned to the medical records section, so that if a patient is treated again, medical records can be quickly provided

Another problem related to KLPCM (Incompleteness of Filling in Medical Records) is that the medical record officer does not record or clearly mark which part must be completed, the officer only writes the sheet that must be completed without writing or marking which part of the sheet must be completed. Another problem is that medical record officers often pay less attention to medical personnel who have to complete medical records, so that they often mistakenly provide files, one example is that there is a sheet that should be the responsibility of the emergency room officer but is given to the room nurse.

Researchers tried to analyze the problem with the competence of medical record officers. Based on the data obtained, it turns out that there are only 1 out of 22 officers in the medical records department who have medical records education. This is clearly very influential for medical record officers in carrying out their duties, because most of the officers have a non-medical record education, so these officers do not have basic knowledge related to implementation. This condition is not in line with government regulations that what is called a medical record officer / medical recorder based on Permenkes number 55 of 2013 Chapter I on the Implementation of Medical Record Work, is someone who has passed medical record education $\&$ health information in accordance with the provisions of laws and regulations. While the medical record officer / medical recorder at Muhammadiyah Hospital who meets the qualifications of the Minister of Health regulation is only 1 person and the other 21 are medical record officers who are non-medical records. In addition, medical recorders as executors of medical records work must be required to have a Registration Certificate. (STR), where STR can be managed if you have a certificate of competence and a certificate of competence can be obtained if someone has passed medical record education in accordance with laws and regulations. Whereas in the SNARS 1.1 accreditation guide on the Competency and Authority Staff Instrument (KKS), the aims and objectives of the KKS 5 standard are that competent non-clinical staff members are recruited through a uniform process with other staff recruitment processes. This process ensures that education, competence, the authority, skills, knowledge and experience of non-clinical staff initially onwards according to the stipulated requirements. This means that from the start, medical record officers as non-clinical staff must have education and competence as medical recorders.

Information from informants other than medical record officers mostly did not have competence as medical recorders, as well as lack of training in the field of medical records. According 
to information, only 2 medical record officers have attended exhouse training for medical records, while the rest have participated in in-house medical record training, which has only been done 2 times. This condition is not in line with Law Number 13 Year 2003 concerning Manpower, Chapter V concerning job training, paragraph 11 states that every worker has the right to obtain and / or improve and / or develop work competence according to their talents, interests and abilities through job training. Whereas in the SNARS 1.1 accreditation guide the competency standard \& The authority of staff (KKS) standard 8 on education and training states that every staff participates in education or training inside or outside the hospital, to maintain and improve competence. This means that every institution such as the Muhammadiyah Ponorogo General Hospital has an obligation to fulfill the rights of its staff to attend training, including medical record officers, most of whom do not have competence as medical records, which later functions to improve the competence and quality of medical record officers in providing services to customers internal.

The question dimension that has the largest gap value is responsiveness. The question of responsiveness is related to the speed with which medical record officers provide medical records needed by medical officers in providing services to patients. The problem related to responsiveness is the lack of speed for medical record officers in providing medical records. Some of the incidents that were conveyed by the informants, among others, were in the ICU room when the old pasin entered the ICU room, especially at night, sometimes medical records were not included, because only 1 person was there in the medical record office at night. In addition, the distance between the ICU room and the medical record room is rather far apart where the ICU room is still in the old building and the medical record room is in the new building. The informant also said that sometimes the medical records were not delivered, so the ICU officers often wanted them to. This condition if allowed to continue will also hinder the process of service to patients, where medical personnel really need medical records to record and see the history of the patient's condition. This is in accordance with the order of Permenkes number 269 of 20018 concerning Chapter III Medical Records on Procedures for Implementation of article 5 paragraph 2 which states that medical records as referred to in paragraph (1) must be made immediately and completed after the patient receives service.

An example of the second problem related to the responsiveness of officers is in the emergency room, the emergency room officer receives a compalin from the patient's family because the patient after receiving initial medical service in the emergency room and according to the doctor's recommendation must be inpatient waiting for a long time not to be transferred to the treatment room because the medical record has not been delivered by officers to the ER. According to information from the informant, this is possible from the distance between the ER and the medical record room, where the ER is still in the old building and medical records in the new building.

The two examples of the problems above are very ironic with Permenkes number 129 of 2008 concerning Minimum Hospital Service Standards, which is mentioned in attachment number 14 concerning medical records, which states that the time for providing medical record documents for outpatient services (including IGD) is $\leq 10$ minutes and time to provide medical record documents for inpatient services (including ICU) $\leq 15$ minutes.

\section{CONCLUSION}

The reliability of officers in the medical record section has the greatest gap value because the informant said that medical record officers sometimes did not include old medical records, thus prolonging the patient service process, besides this the record officer sometimes took a long time to send medical records to the room (ICU), thus hampering the process. service to patients. Management of Incompleteness of Filling in Medical Records (KLPCM) also encountered problems, including medical record officers sending incorrect medical records and unclear which medical record forms to complete. Apart from this, the competence of medical record officers is still lacking, this is due to the very limited number of medical record officers with a Diploma 3 degree of Medical Record education and a lack of medical record training for officers in the medical record division. Centralization of patient registration sites, filing rooms, Emergency Room and ICU and development of electronic medical records.

\section{ACKNOWLEDGMENTS}

Researchers would like to thank and appreciate all informants who have provided information to researchers. Researchers specifically thank the director of Muhammadiyah Hospital of Ponorogo and the head of the medical records unit and his staff who have helped the research process. 


\section{CONFLICTS OF INTEREST:}

This study has no conflict of interest.

\section{REFERENCES}

Arizona, WA, Wibowo, SN and Damayanti Dian. 2014, Analysis of the Service Quality of the Medical Record Unit Based on Internal Customer Satisfaction Using Service Quality and Quality Function Deployment Methods at RSD Kalisat Jember, Indonesian Journal of Health Information Management, Vol. 2, No.1, page 16-25, Jakarta

Azwar Azrul. 2007, Maintaining Health Service Quality Application of Problem Solving Circle Principles, Pustaka Sinar Harapan, Jakarta

Azwar Azrul. 2010, Introduction to Health Administration, Third Edition. Binarupa Aksara Publisher, Jakarta

Budi, Savitri Citra. 2011, Management of Medical Records Work Unit. Quantum Sinergis Media, Yogyakarta

Chairil Anwar Pohan. 2013, Health Service Quality Assurance, PT Gramedia Pustaka Utama, Jakarta

Ministry of Health of the Republic of Indonesia. 2006, Guidelines for the Implementation and Procedure of Hospital Medical Records in Indonesia, Revision 2, Jakarta

Efendi F. 2009, Community Health Nursing: Theory and Practice in Nursing, Volume 1, Salemba Medika, Jakarta

Fandy Tjiptono. 2008, Marketing Strategy, Edition III, CV Andi Offset, Yogyakarta

Gultom, JR 2008, Analysis of Patient Satisfaction with Outpatient Services in Azra Hospital Polyclinic, 2008. Thesis, Faculty of Public Health, University of Indonesia

Hadi, Sutrisno. 2015, Statistics, Student Library, Yogyakarta

Hanifah, MJ and Amir, A. 2008, Medical Ethics and Health Law, 4th Edition, EGC, Jakarta

Hatta, Gemala R. 2014, Guidelines for Health Information Management in Health Service Facilities, UI Press, Jakarata

Lubis Sari, PS and Zebua Putri. 2019, Analysis of the Service Quality of the Medical Record Unit Based on Internal Customer Satisfaction Using Service Quality and Quality Function Deployment Methods at RSU IPI Medan in 2018, Imelda Nursing Scientific Journal, Volume 5, Issue 1 , Medan

Ministry of Health. 2008. Regulation of the Minister of Health No.269 / Menkes / PER / III / 2008, Concerning Medical Records, Jakarta, Ministry of Health of the Republic of Indonesia

Ni Putu, TCDK 2013, JKBM Service Quality Towards Satisfaction Levels of Dental and Oral Patients at Public Health Centers in Denpasar City, http://umnas-library.ac.id/wpcontent/uploads/2014/04/setsa4.pdf

Notoatmodjo, S. 2010, Health Research Methodology, Rineka Cipta, Jakarta

Nursalam. 2016, Practical Approach Nursing Research Methodology, 4th Edition, Salemba Medika, Jakarta

Indonesian government. 2009. Law no. 44 of 2009 concerning the Hospital. RI Gazette of 2009 No. 153. Jakarta: State Secretariat

Sugiyono. 2015, Combination Research Methods (Mix Methods), Alfabeta, Bandung

Supriyanto, S and Ernawaty, 2010, Marketing of Health Services Industry, Andi Yogyakarta

Supriyanto, S and Ratna Wulandari. 2011, Health Service Quality Management, Surabaya Health Advocacy, Surabaya 